\title{
Linking Phenology and Biomass Productivity in South Dakota Mixed-Grass Prairie
}

\author{
Matthew Rigge, ${ }^{1}$ Alexander Smart, ${ }^{2}$ Bruce Wylie, ${ }^{3}$ Tagir Gilmanov, ${ }^{2}$ and Patricia Johnson ${ }^{4}$ \\ Authors are ${ }^{1}$ Range Ecologist, Arctic Slope Regional Corporation Research \& Technology Solutions, Contractor to US Geological Survey, Earth Resources \\ Observation and Science Center, Sioux Falls, SD 57198, USA; ${ }^{2}$ Professor, Department of Natural Resource Management, South Dakota State University, \\ Brookings, SD 57007, USA; ${ }^{3}$ Research Physical Scientist, US Geological Survey, Earth Resources Observation and Science Center, Sioux Falls, SD 57198, \\ USA; and ${ }^{4}$ Professor, Department of Natural Resource Management, South Dakota State University, West River Agricultural Center, Rapid City, SD
} 57702, USA.

\begin{abstract}
Assessing the health of rangeland ecosystems based solely on annual biomass production does not fully describe the condition of the plant community; the phenology of production can provide inferences about species composition, successional stage, and grazing impacts. We evaluated the productivity and phenology of western South Dakota mixed-grass prairie in the period from 2000 to 2008 using the normalized difference vegetation index (NDVI). The NDVI is based on 250-m spatial resolution Moderate Resolution Imaging Spectroradiometer (MODIS) satellite imagery. Growing-season NDVI images were integrated weekly to produce time-integrated NDVI (TIN), a proxy of total annual biomass production, and integrated seasonally to represent annual production by cool- and warm-season species $\left(\mathrm{C}_{3}\right.$ and $\mathrm{C}_{4}$, respectively). Additionally, a variety of phenological indicators including cool-season percentage of TIN were derived from the seasonal profiles of NDVI. Cool-season percentage and TIN were combined to generate vegetation classes, which served as proxies of the conditions of plant communities. TIN decreased with precipitation from east to west across the study area. However, the cool-season percentage increased from east to west, following patterns related to the reliability (interannual coefficient of variation [CV]) and quantity of midsummer precipitation. Cool-season TIN averaged $76.8 \%$ of the total TIN. Seasonal accumulation of TIN corresponded closely $\left(R^{2}>0.90\right)$ to that of gross photosynthesis data from a carbon flux tower. Field-collected biomass and community composition data were strongly related to TIN and cool-season percentage. The patterns of vegetation classes were responsive to topographic, edaphic, and land management influences on plant communities. Accurate maps of biomass production, cool- and warm-season composition, and vegetation classes can improve the efficiency of land management by facilitating the adjustment of stocking rates and season of use to maximize rangeland productivity and achieve conservation objectives. Further, our results clarify the spatial and temporal dynamics of phenology and TIN in mixed-grass prairie.
\end{abstract}

Key Words: $\mathrm{C}_{3}$ and $\mathrm{C}_{4}$ species, land management, Moderate Resolution Imaging Spectroradiometer (MODIS), plant communities, remote sensing

\section{INTRODUCTION}

The phenology of biomass production by $\mathrm{C}_{3}$ and $\mathrm{C}_{4}$ plants is significant in assessing rangeland health due to inferences that can be made about species composition (Reed et al. 1994; Tateishi and Ebata 2004). Differentiation of rangeland plant communities by photosynthetic pathway ratios is of critical importance due to the great difference in the exchanges of $\mathrm{CO}_{2}$, water, and energy between $\mathrm{C}_{3}$ and $\mathrm{C}_{4}$ plants (Sims and Singh 1978; Tieszen et al. 1997) and is needed to describe community status in state-and-transition models. Rangeland monitoring protocols would therefore be more comprehensive if observations on both the timing and magnitude of biomass production were included.

Although remote sensing cannot usually detect traditional phenological events such as budding and flowering (Tieszen et

Research was funded by the USDA Conservation Effects Assessment Project (CEAP) 2009-51130-06014, and the US Geological Survey, Climate and Land Use Change Program, Research and Development Program. Work was performed under USGS contract G08PC91508.

Correspondence: Matthew Rigge, US Geological Survey Earth Resources Observation and Science Center, 47914, Sioux Falls, SD 57198, USA. Email: mrigge@usgs.gov

Manuscript received 10 July 2012; manuscript accepted 11 April 2013.

(c) 2013 The Society for Range Management al. 1997), it can detect important phenological indicators such as the onset of the growing season, the end of the growing season, senescence, rate of green-up, and peak vegetation vigor using a series of satellite images over a growing season (Reed et al. 1994; Tao et al. 2008; van Leeuwen et al. 2010; Kovalskyy and Henebry 2012). Rangeland plant communities dominated by either $\mathrm{C}_{3}$ or $\mathrm{C}_{4}$ species can be often be identified through their unique and asynchronous phenologic profiles (Foody and Dash 2007). Grasses with $C_{3}$ pathways are most active during the cooler spring and fall seasons, while many $\mathrm{C}_{4}$ grasses are adapted to the hot and dry summer months (Tieszen et al. 1997; Foody and Dash 2007; Wang et al. 2010). State-andtransition models for many ecological sites of the northern mixed prairie indicate that $\mathrm{C}_{3}$ species tend to dominate the historic climax plant communities, while $\mathrm{C}_{4}$ shortgrass species generally increase under heavy, continuous, season-long grazing (US Department of Agriculture [USDA] 2008a).

Land management, livestock grazing, invasion of exotic species, and prolonged droughts all have the potential to alter rangeland plant community structure (and consequently contribute to altered phenological patterns; Tieszen et al. 1997; Foody and Dash 2007). These factors also have the potential to modify ecosystem goods and services (Bradley and Mustard 2008). Monitoring the biomass production and phenology of rangelands is important to detect and preclude 
any deleterious trends caused by land management (Paruelo and Lauenroth 1998), specifically to avoid shifts across thresholds in state-and-transition models. Changes in plant community structure are associated with shifts in the timing of growth initiation, reproduction, senescence (Bradley and Mustard, 2008), and biomass production, all of which can be detected remotely. Although a variety of metrics can be used to describe the health of rangelands, annual biomass production and $\mathrm{C}_{3} / \mathrm{C}_{4}$ percentage are most critical to determining the community status (in state-and-transition models) in the northern mixed-grass prairie (USDA 2008a-d).

Our objectives were to use 250-m-resolution remotely sensed Normalized Difference Vegetation Index (NDVI) data to: 1) describe the spatial and temporal patterns of the a) phenology and b) time-integrated NDVI (TIN; a proxy of annual biomass production [Tieszen et al. 1997]) of rangelands in the northern mixed-grass prairie, specifically to clarify their dynamics in relation to precipitation and to each other; 2) link TIN with phenology to produce vegetation classes, which are a proxy of plant communities and an indicator of rangeland condition; 3) evaluate the spatial patterns in vegetation communities; and 4) assess the accuracy of our remotely detected results, as compared to several field-collected data sources.

\section{MATERIALS AND METHODS}

\section{Site Description}

This study was conducted in the Bad River watershed of western South Dakota in the northern mixed-grass prairie. The Major Land Resource Area (MLRA) is the Northern Rolling Pierre Shale Plains (63A), dominated by the Clayey ecological site (USDA 2008a). Much of the region is typified by long, smooth slopes, with steeper slopes along well-defined waterways. Throughout the watershed, the bedrock is Pierre Shale, resulting in soils with a high clay content and low permeability.

The semiarid landscape of the Bad River watershed ( lat $45^{\circ} \mathrm{N}$, long $101^{\circ} \mathrm{W}$ ) received an average of $398 \mathrm{~mm}$ precipitation annually over the 2000-2008 period $^{1}$ of which $80 \%$ occurred during the growing season of April to September. Annual precipitation is highly variable, with drought and insufficient moisture common (Barker and Whitman 1988). The daily mean temperature ranges from $32^{\circ} \mathrm{C}$ in July to $-14^{\circ} \mathrm{C}$ in January, with a yearly mean of $8^{\circ} \mathrm{C}$ (Smart et al. 2007). Using PRISM data, we calculated: 1) average annual precipitation, 2) average growing-season precipitation, and 3) average seasonal (spring [April to June], summer [July and August], and fall [September and October]) precipitation at each pixel and also averaged across the study area. Additionally, we calculated the interannual CV (coefficient of variation) in precipitation for each seasonal period for each pixel.

Analysis was restricted to areas classified in the National Land Cover Database 2006 as herbaceous cover (Fry et al. 2011), which we identified as rangelands. Major roads, forested areas, wetlands, cropland, and cities were buffered by $100 \mathrm{~m}$. These buffered areas were excluded to avoid mixed

\footnotetext{
${ }^{1}$ Parameter-Elevation Regressions on Independent Slopes Model [PRISM] Climate Group, Oregon State University, http://www.prismclimate.org.
}

pixels and to ensure a pure rangeland vegetation signal. Our study area then consisted of 450000 ha, or $55 \%$ of the total watershed area.

Vegetation. The study area is predominantly mixed-grass rangeland dominated by $\mathrm{C}_{3}$ grasses including western wheatgrass (Pascopyrum smithii Rybd.) and green needlegrass (Stipa viridula Trin. \& Rupr.; Smart et al. 2007). The shortgrass $\mathrm{C}_{4}$ component includes buffalograss (Bouteloua dactyloides Nutt.) and blue grama (Bouteloua gracilis H.B.K.), which tend to contribute a smaller portion of total herbage production. Additionally, highly productive and palatable $\mathrm{C}_{4}$ grasses including big bluestem (Andropogon gerardii Vitman), little bluestem (Schizachyrium scoparium [Michx.] Nash), switchgrass (Panicum virgatum L.), and sideoats grama (Bouteloua curtipendula [Michx.] Torr.) occur in smaller amounts, predominately in the eastern portion of the watershed and riparian areas (Barker and Whitman 1988). Forb and succulent cover is limited (Sims et al. 1978; USDA 2008a).

Plant Communities. The western wheatgrass/green needlegrass community is considered to be the historic climax plant community in the Clayey ecological site (the dominant site in the study area), and is associated with sites properly managed with grazing (USDA 2008a). The state-and-transition model of this site suggests that continuous grazing during the same season for multiple years or utilization during extended drought can cause a shift to the western wheatgrass/blue grama/buffalograss community, with a smaller component of cool-season species and lower productivity than the western wheatgrass/green needlegrass community. Heavy seasonal grazing or heavy, continuous season-long grazing can push the western wheatgrass/blue grama/buffalograss community across a threshold to the blue grama/buffalograss sod community with an even higher warm-season component and lower productivity (USDA 2008a).

\section{Remotely Sensed Data}

We utilized temporally smoothed (Swets et al. 2000) 250-m eMODIS weekly composite Terra MODIS imagery (Jenkerson et al. 2010) for 2000 to 2008. NDVI, a relative proxy for vegetation productivity (Tieszen et al. 1997; Wylie et al. 2002), was calculated from the imagery. In this study, NDVI values were rescaled to a range of 0 to 200 following Zhang et al. (2011) to simplify calculations by eliminating negative values. Hereafter, rescaled NDVI will be referred to as mNDVI (modified NDVI), with the TIN created from mNDVI still referred to as TIN.

Productivity Analysis. A variety of phenological measurements (phenometrics) were utilized in this study to describe plant communities. The start of the season was calculated for each pixel as the first point in time each year when mNDVI reached $20 \%$ of the total growing-season mNDVI amplitude of that year (van Leeuwen et al. 2010; Fig. 1). The total growingseason amplitude itself was calculated as the difference between the peak mNDVI value (during the 1 April to 31 October growing season) and the minimum mNDVI value during this period (Fig. 2). Similarly, the end of the season was the time at which the mNDVI value dropped below $20 \%$ of the total growing-season mNDVI amplitude. The actual mNDVI value 


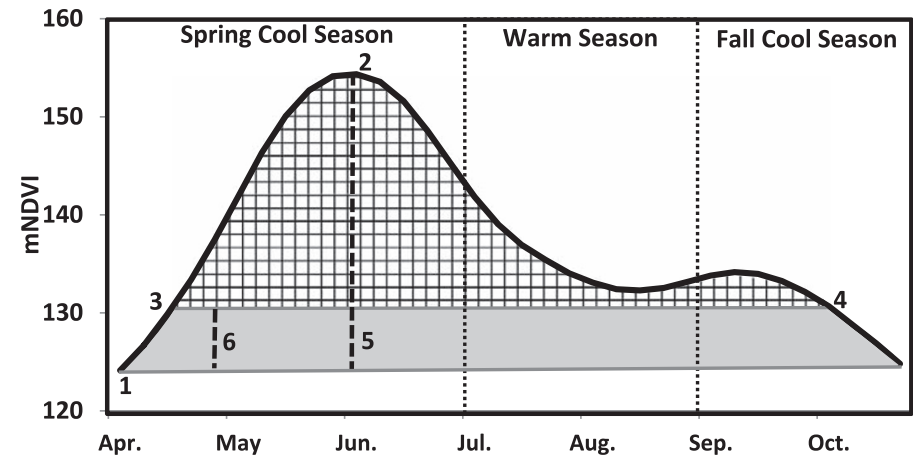

Figure 1. Calculation of the main phenometrics used in this study. The solid black line represents the modified NDVI (mNDVI) phenologic profile of a representative Moderate Resolution Imaging Spectroradiometer pixel. The gridded area corresponds to the portion of the mNDVI profile included in the yearly time-integrated mNDVI (TIN). The spring, summer, and fall growingseason TIN compilation periods are separated by dashed lines. Annotations represent 1) growing-season minimum mNDVI, 2) growing-season peak mNDVI, 3) start of season, 4) end of season, 5) total growing-season amplitude, and 6) $20 \%$ of total growing-season amplitude. The gray shaded area corresponds to the portion of the phenological profile below the " $20 \%$ of growing-season mNDVI amplitude" baseline that was not included in the calculation of TIN.

at the " $20 \%$ of total growing-season amplitude" threshold varied in both space and time, because it was proportional to the maximum and minimum mNDVI. While other thresholds $(10 \%$ and $30 \%)$ were evaluated, the " $20 \%$ of total mNDVI amplitude" generated start-of-season dates best corresponding with those in the ecological site description (i.e., monthly plant growth curves; USDA 2008a). Growing-season length was calculated as the total number of weeks in which the mNDVI was greater than the " $20 \%$ of total amplitude" level.

The time-integrated mNDVI (TIN) (Tieszen et al. 1997) was calculated independently for each pixel within each year by

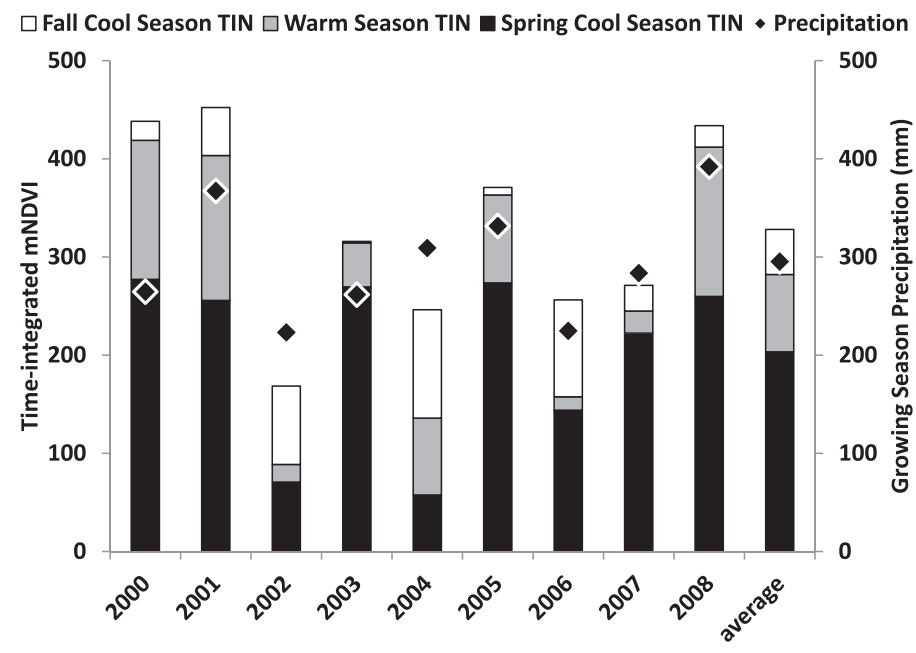

Figure 2. Average yearly contribution of seasonal (spring, warm-season [summer], and fall) time-integrated modified NDVI (TIN) periods to the total yearly TIN in western South Dakota rangelands. The sum of the three seasonal periods corresponds to total yearly TIN. Study area average growing-season (April-October) precipitation is displayed on the secondary vertical axis. integrating the weekly mNDVI that were above the $20 \%$ baseline throughout the growing season (i.e., the area below the smoothed mNDVI curve and above the " $20 \%$ of total seasonal mNDVI amplitude" level, represented as the gridded area in Fig. 1). The portion of the mNDVI profile below the " $20 \%$ of growing-season amplitude" baseline (depicted as the gray shaded area in Fig. 1) was not included in the calculation of TIN, and is likely soil and background noise. Our approach better captures the total seasonal biomass production than simply averaging NDVI over the growing season (Tieszen et al. 1997). In this study, TIN served as a proxy for growing-season total biomass production. Because TIN is influenced by the magnitude and duration of mNDVI values, the saturation effects that occur at high NDVI values (Huete et al. 2002) are minimized. Although mNDVI has been integrated over an entire growing season to calculate TIN, integrations of mNDVI over other time periods can obtain superior results (Wang et al. 2005). In addition to calculating total growing-season TIN, we calculated the TIN of the following periods (Fig. 1): spring cool season (start of season to 30 June), warm season (July and August), and fall cool season (1 September to end of season).

Cool- and Warm-Season Periods. In the northern mixed-grass prairie, the majority of $\mathrm{C}_{3}$ production occurs in spring and fall, and most $\mathrm{C}_{4}$ production occurs in summer, although there is both spatial and temporal overlap in production (Ode et al. 1980). For example, both $\mathrm{C}_{3}$ and $\mathrm{C}_{4}$ plants actively produce biomass in mid- to late June with no clear separation between the timing of their production (Ode et al. 1980; USDA 2008a). The 1 July to 31 August period is typically (although not always) dominated by $\mathrm{C}_{4}$ grasses in the study area and was therefore used to define the warm-season period (Ode et al. 1980; White 1983; Wang et al. 2010; Fig. 1). Hereafter, the periods typically dominated by the $\mathrm{C}_{3}$ pathway will be referred to as the spring or fall cool season, while the period dominated by the $\mathrm{C}_{4}$ pathway will be referred to as the warm season, because these periods do not contain a pure photosynthetic pathway signal. The cool-season percentage was defined as the sum of TIN from the spring and fall cool-season periods divided by the total growing-season TIN.

Vegetation Classes. The 2000-2008 average TIN was grouped into three classes: 1) within one standard deviation of the study area mean, 2) below one standard deviation of the mean, and 3) above one standard deviation of the mean. A similar approach was used to group the 2000-2008 average cool-season percentage into three classes. The TIN and coolseason percentage classes were integrated to form nine vegetation classes, representing the average of the 2000-2008 conditions (Table 1).

\section{Validation}

Pasture Biomass and Phenology. Field and carbon flux tower data were collected at the Cottonwood Range and Livestock Research Station (CRLRS). The vegetation, soils, weather, and topography at the CRLRS (lat $43^{\circ} 94^{\prime} \mathrm{N}$, long $101^{\circ} 85^{\prime} \mathrm{W}$ ) (Sims et al. 1978; Smart et al. 2007; Dunn et al. 2010) were representative of the Bad River watershed and the Northern Great Plains mixed-grass prairie (USDA 2008a). CRLRS is dominated by the Clayey ecological site. Three distinct plant 
Table 1. Vegetation classifications based on time-integrated modified NDVI (TIN) and cool-season percentage of TIN in western South Dakota rangelands from 2000 to 2008. Classes marked with "+" indicate an actual TIN or cool-season percentage over one standard deviation higher than the study area average. Similarly, classes marked with "-" indicate an actual TIN or cool-season percentage that is less than one standard deviation below average. Classes marked with "N" indicate normal performance within one standard deviation of the average value. Means followed by a different letter $\mathrm{a}-\mathrm{i}$ indicate a significant difference $(P<0.05)$ within a column.

\begin{tabular}{lllccc}
\hline Vegetation class & TIN $^{1}$ & CS\% $^{2}$ & Area $^{3}(\%)$ & ${\text { Mean } \text { TIN }^{1}}$ & Mean CS\% \\
\hline 1 & - & - & 4.7 & $268.2 \mathrm{i}$ & $74.5 \mathrm{~g}$ \\
2 & $\mathrm{~N}$ & - & 8.8 & $329.0 \mathrm{~d}$ & $74.7 \mathrm{~h}$ \\
3 & + & - & 19.1 & $389.4 \mathrm{a}$ & $73.7 \mathrm{i}$ \\
4 & - & $\mathrm{N}$ & 10.2 & $279.2 \mathrm{~g}$ & $80.3 \mathrm{~d}$ \\
5 & $\mathrm{~N}$ & $\mathrm{~N}$ & 12.8 & $327.3 \mathrm{e}$ & $80.0 \mathrm{e}$ \\
6 & + & $\mathrm{N}$ & 10.3 & $376.7 \mathrm{~b}$ & $79.8 \mathrm{f}$ \\
7 & - & + & 18.1 & $270.1 \mathrm{~h}$ & $85.7 \mathrm{a}$ \\
8 & $\mathrm{~N}$ & + & 11.5 & $325.0 \mathrm{f}$ & $85.0 \mathrm{~b}$ \\
9 & + & + & 4.5 & $370.7 \mathrm{C}$ & $84.7 \mathrm{C}$ \\
\hline
\end{tabular}

${ }^{1}$ Time-integrated modified NDVI (TIN).

${ }^{2} \mathrm{Cool}$-season percentage of TIN.

${ }^{3}$ Vegetation-class percentage of study area.

communities were maintained under long-term (>30-year) differences in grazing management (Dunn et al. 2010). We chose to evaluate two of the three plant communities (mixedgrass and midgrass-dominated) because the pasture size of the shortgrass community was too small for the 250-m MODIS pixels to resolve without interference from surrounding pastures. The midgrass-dominated community represents the historic climax plant community. Both plant communities were replicated (i.e., two $\sim 60$-ha pastures of each), and represented by 16 total pixels ( 8 in the mixed-grass and 8 in the midgrassdominated pastures). The remotely detected TIN and coolseason percentage were extracted at each point for each year that field data were available (2000-2005) and subsequently averaged yearly by pasture and by plant community.

Field-measured vegetation data in each pasture at CRLRS were collected using movable exclusion cages to estimate species composition by weight in late June (peak cool-season biomass) and early August (peak warm-season biomass). The sampling scheme consisted of 14 cages per pasture placed in a nonrandom fashion to represent the internal variation in soil type, slope, and aspect. Species biomass was estimated using a nondestructive double sampling technique with reference units (Andrew et al. 1979; Andrew et al. 1981) and plant volume (Johnson et al. 1988). Field-measured data were compiled for each pasture into yearly cool-season biomass production $\left(\mathrm{kg} \cdot \mathrm{ha}^{-1}\right)$, warm-season production, total production, and cool-season proportion of the total, and also averaged by plant community. The remotely sensed yearly average TIN and coolseason percentage for each pasture were regressed against the corresponding field-measured average biomass production and cool-season percentage data $(n=24)$. A two-sided, two-sample, $t$ test was used to test for differences between the annual mean field-measured and remotely detected phenometrics of the mixed-grass and midgrass community $(n=6)$.
Carbon Flux Tower. Another source of validation data was from a carbon flux tower located on one of the mixed-grass plant community pastures at CRLRS, available in 2007 and 2008. Thirty-minute flux tower quality-controlled Net Ecosystem Productivity data were modeled using nonlinear light response curves driven by photosynthetically active radiation (PAR), soil temperature, and vapor pressure deficit to partition carbon fluxes associated with PAR (i.e., gross primary productivity) from those associated with total ecosystem respiration (Gilmanov et al. 2010). The gross photosynthesis (PG) data used in this study were defined as the sum of daytime $\mathrm{CO}_{2}$ flux and daytime respiration, minus the rate of change in $\mathrm{CO}_{2}$ storage in the atmospheric layer below the tower $\mathrm{CO}_{2}$ sensor. Time-series data (i.e., growing-season phenological profile) of average weekly PG $\left(\mathrm{g} \mathrm{CO}_{2} \cdot \mathrm{m}^{-2} \cdot \mathrm{d}^{-1}\right)$ were utilized to generate phenometrics using the same methods employed for eMODIS data (Fig. 1), making the results generated from both data sets more directly comparable.

\section{RESULTS AND DISCUSSION}

\section{Time-Integrated mNDVI}

The average yearly contribution of cool- and warm-season TIN was highly variable during the 9-yr study period (Figs. 2 and 3). This degree of phenological variability is common in rangeland environments (Tieszen et al. 1997), with complex native plant communities (Smart et al. 2007) responding to the high interannual variation in precipitation (Lauenroth and Sala 1992). The dependability of production from seasonal TIN periods was determined from an interannual coefficient of variation $(\mathrm{CV})$. The fall cool-season TIN had the highest interannual $\mathrm{CV}$ of $83 \%$, followed by the warm-season TIN with a CV of $73 \%$, and the spring cool-season TIN with $43 \%$. The CVs of the seasonal TIN periods were related to the reliability of precipitation during each period, with spring coolseason moisture having the lowest interannual CV of $49 \%$,

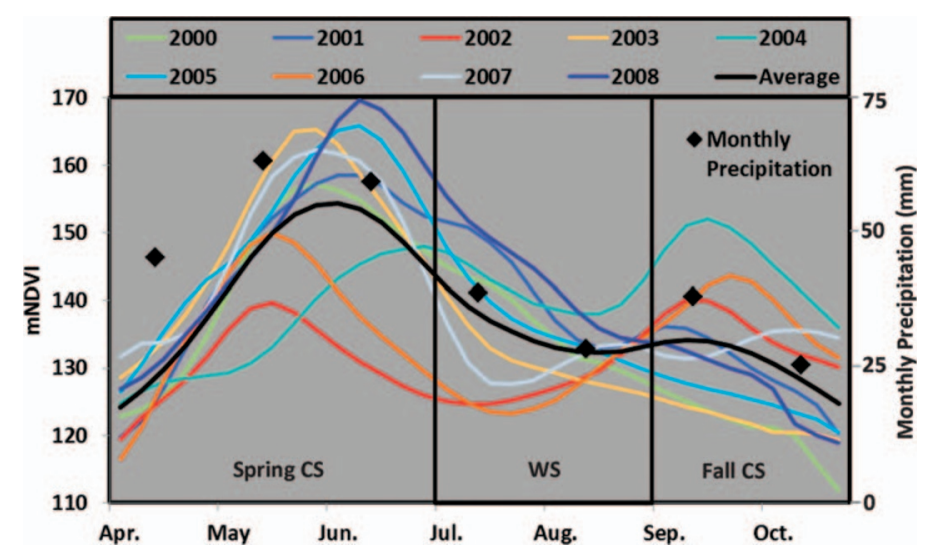

Figure 3. Average phenologic profile in western South Dakota rangelands from 2000 to 2008. Years are colored according to growing-season precipitation, ranging from red in dry years to blue in wet years (for color, the reader is referred to the online version of this article). The 2000-2008 average monthly precipitation is given on the secondary vertical axis. The black rectangle contains the warm-season (WS) period. Spring and fall cool-season (CS) periods are outside the rectangle in the regions to the left and right of the warm season. 
Table 2. Matrix of coefficient of determination $\left(R^{2}\right)$ values for annually averaged phenometrics in western South Dakota rangelands for 2000 2008. Abbreviations; GSP: growing-season precipitation (mm), CS: cool season, WS: warm season, and TIN: time-integrated modified NDVI. Bold values indicate a negative relationship.

\begin{tabular}{lcccccc}
\hline \multicolumn{1}{c}{ Variable } & GSP & Spring CS TIN & WS TIN & FALL CS TIN & TIN & CS TIN (\%) \\
\hline GSP & - & - & - & - & - & - \\
Spring CS TIN & 0.20 & - & - & - & - & - \\
WS TIN & 0.60 & 0.28 & - & - & - & - \\
Fall CS TIN & $\mathbf{0 . 1 0}$ & $\mathbf{0 . 8 5}$ & $\mathbf{0 . 1 4}$ & - & - & - \\
TIN & 0.50 & 0.67 & 0.81 & $\mathbf{0 . 3 9}$ & - & - \\
CS TIN\% & $\mathbf{0 . 5 9}$ & $\mathbf{0 . 0 9}$ & $\mathbf{0 . 8 9}$ & 0.04 & $\mathbf{0 . 5 4}$ & - \\
\hline
\end{tabular}

compared to the warm-season moisture CV of $69 \%$. The spring cool-season TIN contributed an average of $62 \%$ to the total TIN, with the warm season contributing $24 \%$, and the fall cool season, $14 \%$, respectively (Fig. 2). The total cool-season (spring and fall) TIN averaged $77 \%$ of the total growing-season TIN, which is close to previously reported values for the region (Sims et al. 1978; Tieszen et al. 1997; Foody and Dash 2007).

During the growing season, precipitation was most variable in July and August (warm season), while precipitation in the spring cool-season period (April to June) was more reliable. Droughts were often characterized by a lack of growing-season precipitation, particularly in the warm season, leading to reduced total TIN (especially in the warm-season period), and subsequently a higher cool-season percentage of total TIN (Figs. 2 and 3, Table 2). For this reason, the warm-season TIN was more strongly related to growing-season precipitation than were the spring cool-season TIN, fall cool-season TIN (which had a negative relationship), and total growing-season TIN, a pattern supported by previous research (Ricotta et al. 2003; Table 2). Accordingly, a negative temporal relationship existed between the cool-season percentage and growing-season precipitation $\left(R^{2}=0.59, P<0.01\right)$ and with total TIN $\left(R^{2}=0.54, P<0.01\right.$; Table 2). Because the temporal $\mathrm{CV}$ of the spring precipitation was relatively low, the higher amounts of total growing-season moisture were often due to greater levels of warm-season moisture, leading to the previously described relationships. The temporal correlation between growing-season precipitation and total TIN $\left(R^{2}=0.50\right.$, $P<0.05, n=9)$ compares favorably to the relationship reported by Webb et al. (1978) in semiarid rangelands. Although precipitation is a significant driver of productivity in the mixed-grass prairie, other factors such as temperature, precipitation in previous years, and disturbance can also have a strong influence (Smart et al. 2007).

\section{Geographic Patterns of Time-Integrated mNDVI}

The landscape gradient of the 2000-2008 average TIN closely followed the precipitation gradient (Fig. 4) and the general gradient of increased primary production in the Great Plains from west to east described by Sala et al. (1988). On a per pixel (spatial) basis, the relationship between the 2000-2008 average growing-season precipitation and $\operatorname{TIN}\left(R^{2}=0.45, P<0.01\right)$ was slightly weaker than when temporally analyzed. Precipitation, TIN, all seasonal TIN periods, and warm-season

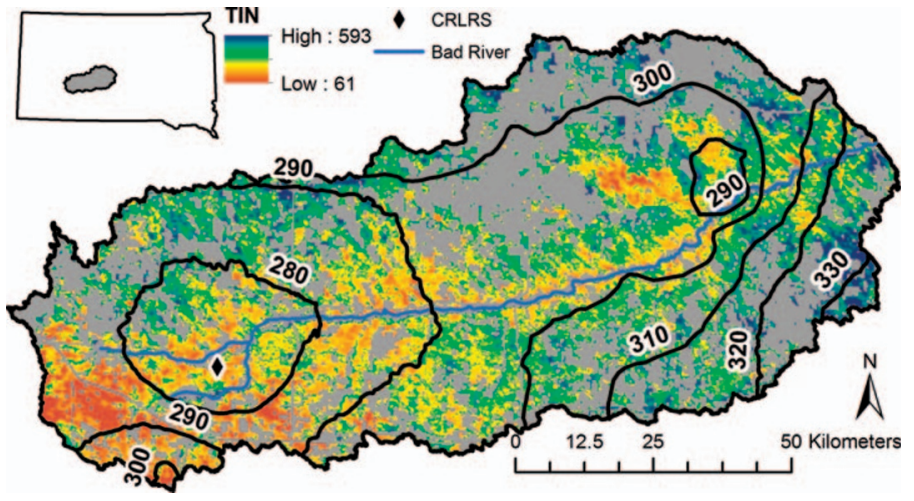

Figure 4. Average time-integrated modified NDVI (TIN) for western South Dakota rangelands from 2000 to 2008. Average growing-season precipitation for the same period is given in 10-mm contours denoted by thick black lines. Gray or hatched areas denote nonrangeland regions excluded from analysis. The Cottonwood Range and Livestock Research Station (CRLRS) is located in the southwest portion of the study area. Inset map depicts the location of the Bad River watershed study area in western South Dakota. For color, the reader is referred to the online version of this article.

percentage increased on the same west-to-east gradient (Figs. 4 and 5).

Precipitation was the single most important determinant in the geographic pattern of TIN; however, topographic and edaphic effects were also important (Fig. 4). For example, the breaks rangelands on the steep, infertile slopes along the Bad River and its major tributaries were unproductive, compared to the flat rangelands surrounding them. In this instance, the low productivity was a product of site potential not management. The region of low TIN and high cool-season percentage in the southwest corner of the study area was due to the presence of badlands with low vegetation cover and infertile soils (Barker and Whitman 1988).

In the Great Plains, aboveground net primary production (ANPP) was predicted to increase at a rate of $0.6 \mathrm{~g} \cdot \mathrm{m}^{-2} \cdot \mathrm{mm}^{-1}$ of precipitation (Sala et al. 1988; Oesterheld et al. 2001). In the Bad River watershed, this would correspond to a $17 \%$ difference in ANPP (i.e., TIN) between precipitation extremes. The actual difference in TIN was much greater, about $80 \%$, underscoring the importance of nonprecipitation biomass production drivers such as grazing, soils, and topography (Fig. 4). Although TIN does not fully describe rangeland health, it is a strong indicator of the energy captured by plants and available to consumers, a measure which is necessary in rangeland health assessments.

\section{Phenology}

The average phenological profile of all rangeland pixels had a start of season in mid-April, followed by a quick increase to the primary peak mNDVI in mid-June (Fig. 3). Years with greater growing-season precipitation tended to have a greater and later primary peak mNDVI, suggesting a stronger warm-season contribution. Conversely, drier years were associated with earlier peak mNDVI. After the primary peak, the mNDVI decreased, sometimes rapidly, through July and August; this was due to the relatively low levels of precipitation that 


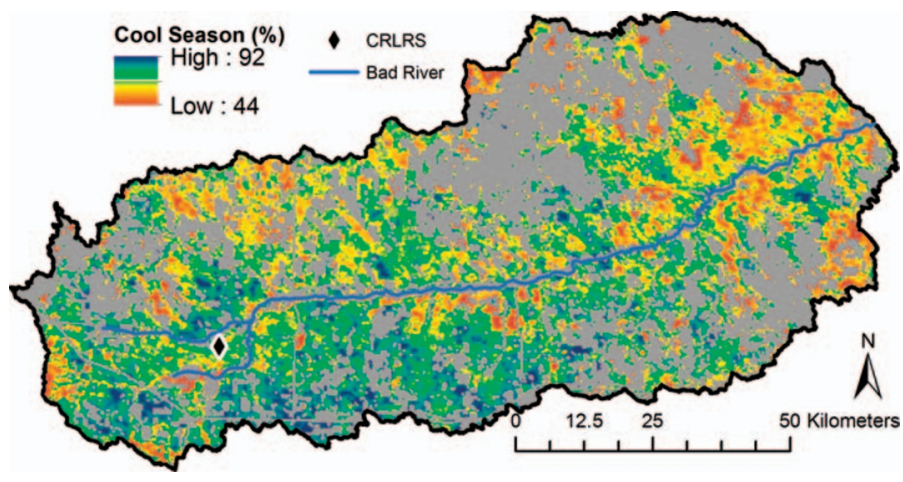

Figure 5. Average cool-season percentage of total time-integrated modified NDVI (TIN) for western South Dakota rangelands from 2000 to 2008. Gray or hatched areas denote nonrangeland regions excluded from analysis. The Cottonwood Range and Livestock Research Station (CRLRS) is located in the southwest portion of the study area. For color, the reader is referred to the online version of this article.

characterize this period. Often, the mNDVI subsequently increased to a secondary cool-season peak in the relatively cooler and wetter September-October period, a pattern also observed by Wang et al. (2010).

In drought years (i.e., 2002, 2004, and 2006), the secondary fall peak was of much greater amplitude than in other years (Figs. 2 and 3), with a mean fall cool-season TIN that was more than double the overall average. The secondary peak was sometimes nearly as great as the primary peak, and in the case of 2004, larger than the primary spring peak. High fall coolseason TIN in drought years may be due to increased tillering of western wheatgrass (Oesterheld et al. 2001) following elevated grazing pressure during drought (Eneboe et al. 2002). Alternatively, during drought years a larger portion of the senesced warm-season vegetation canopy might have been removed by grazing (due to reduced forage availability; Sims et al. 1978), increasing the green vegetation signal (Wylie et al. 1996) and TIN in the fall cool-season period. The spatially averaged 2000-2008 cool-season percentage was $80 \%$, close to the temporally averaged value of $77 \%$.

\section{Geographic Patterns of Phenology}

Because warm-season plants have a competitive advantage under water stress (Ode et al. 1980; Tieszen et al. 1997), one might expect the warm-season percentage to increase with reduced precipitation from east to west. The opposite was the case, however, as the spatial patterns in TIN and cool-season percentage opposed each other (Figs. 4 and 5). TIN decreased from east to west $\left(R^{2}=0.18, P<0.01\right)$ and from north to south $\left(R^{2}=0.14, P<0.01\right.$; Fig. 5), following patterns in precipitation and evapotranspiration. Conversely, the cool-season percentage of total TIN increased from east to west $\left(R^{2}=0.10, P<0.01\right)$ and from north to south $\left(R^{2}=0.17, P<0.01\right.$; Fig. 5). The net result of these patterns was a negative spatial relationship between TIN and cool-season percentage $\left(R^{2}=0.19, P<0.01\right)$ across the study area, following the negative temporal relationship observed between TIN and cool-season percentage (Fig. 2 and Table 2). These patterns were related to the CV of warm-season moisture that tended to increase across the study area from east to west $\left(R^{2}=0.14, P<0.01\right.$; i.e., warm-season moisture was less reliable in the west), while warm-season precipitation quantity decreased from east to west $\left(R^{2}=0.54\right.$, $P<0.01$ ), leaving the eastern portion of the study area with greater and more reliable warm-season moisture-enhancing growth, especially in warm-season species (Ode et al. 1980). At a more local scale, however, an increased cool-season percentage was typically related to increased TIN, similar to the pattern of increased herbage production with a higher coolseason component found by Smart et al. (2007), as would be expected by the state-and-transition model of the Clayey ecological site (USDA 2008a).

\section{Linking Biomass Production and Phenology: Vegetation Classes}

Phenological profiles are often indicative of species composition and vegetation communities (Reed et al. 1994; Tateishi and Ebata 2004) and strongly influence biomass production (Smart et al. 2007). Consequently, combining the cool-season percentage and TIN measurements leads to a better understanding of vegetation dynamics and plant community status than when either is evaluated independently. Our analysis linking phenology and TIN resulted in nine vegetation classes; the attributes of each are presented in Table 1. Vegetation class numbers are indicative of the plant community state, with higher numbers generally approaching the western wheatgrass/ green needlegrass community (historic climax plant community of the Clayey ecological site) and lower numbers generally approaching the blue grama/buffalograss plant community (Smart et al. 2007; USDA 2008a).

The patterns of vegetation classes are critical in describing topographic, edaphic, and land management influences on plant communities (Fig. 6). For example, a site with both a low cool-season percentage and low TIN (class 1) was likely dominated by buffalograss and blue grama, both low-producing $\mathrm{C}_{4}$ species. This community was reported to result from high grazing pressure (Smart et al. 2007; USDA 2008a) in the Clayey ecological site. Alternatively, unfavorable warm-season moisture regimes in Pierre Shale/badland outcrops could result in such a plant community (Fig. 6).

The historic climax plant community of the Clayey ecological site in western South Dakota is largely dominated by moderately to highly productive $\mathrm{C}_{3}$ grasses (classes $5,6,8$, and 9; Table 1, Fig. 6). The relative productivity (TIN) of each site is determined by both soil fertility and grazing intensity. Of these classes, $(5,6,8$, and 9$)$, class 9 sites would be described by the Clayey ecological site state-and-transition model as the most lightly grazed and class 5 sites as the most heavily grazed. Overall, classes 1,2 , and 4 are indicative of a shortgrass community, due to the heaviest grazing pressure and/or least favorable growing conditions. Classes 3, 5, and 7 are presumably dominated by a mixed-grass community, the result of moderate grazing pressure. Finally, classes 6, 8, and 9 suggest a midgrass community, resulting from the lightest grazing pressure and/or most favorable growing conditions.

In the Bad River study area, livestock tend to selectively graze $\mathrm{C}_{3}$ grasses such as western wheatgrass and green needlegrass. Under increased grazing pressure without adequate rest periods for these palatable grasses to regenerate, the state-and-transition model (of the Clayey ecological site) 


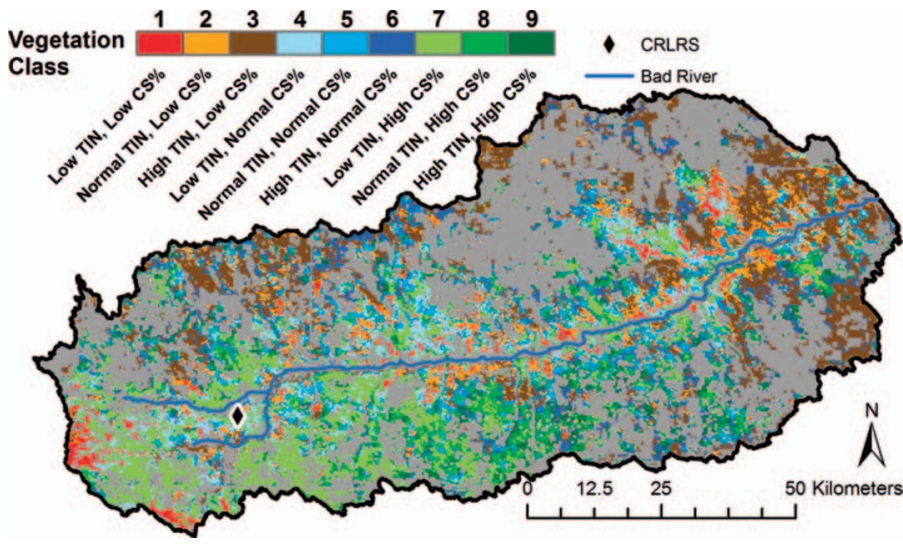

Figure 6. Vegetation class derived from average cool-season percentage (CS\%) and time-integrated mNDVI (TIN) for in western South Dakota rangelands. Light gray areas denote nonrangeland areas excluded from analysis. See Table 1 for explanation of classes.

suggests that plant community structure will shift toward less palatable $\mathrm{C}_{4}$ grasses, including buffalograss and blue grama, resulting in lower biomass production (Barker and Whitman 1988; Smart et al. 2007; USDA 2008a). In a study of western South Dakota rangelands, Smart et al. (2007) observed that transitioning from a $\mathrm{C}_{3}$-dominated midgrass community to a mixed-grass $\mathrm{C}_{3} / \mathrm{C}_{4}$ community corresponded with a 560 $\mathrm{kg} \cdot \mathrm{ha}^{-1}$ or $27 \%$ reduction in biomass production. Our results demonstrate a similar pattern, with the mean TIN of vegetation class 1 (with low TIN and low cool-season percentage) $28 \%$ lower than that of class 9 (with high TIN and high cool-season percentage; Table 1).

An interesting pattern occurred among the high TIN classes 3, 6, and 9: TIN decreased, with an increasing cool-season component, from class 3 to 6 to 9 (Table 1), which is the opposite direction predicted by the state-and-transition model of the Clayey ecological site that encompasses the majority of the study area. Although most $\mathrm{C}_{4}$ grasses in the study area are typically low-producing shortgrass species, this pattern indicated the presence of highly productive $\mathrm{C}_{4}$ species (i.e., big bluestem, little bluestem, switchgrass, and sideoats grama) in about $19 \%$ of the study area rangelands. This pattern would be expected because the eastern (wetter) portion of the mixed-grass prairie and our study area tends to contain a stronger presence of tallgrass species as compared to the western portion of the mixed-grass prairie. Portions of this area may correspond with alternative ecological sites such as Subirrigated (USDA 2008b) or Loamy Overflow (USDA 2008c), which have a tallgrass warm-season historic climax community and often produce more biomass than Clayey ecological sites. Correspondingly, sites with a moderate to high warm-season component and low TIN (vegetation classes 1, 2, and 4) may correspond with ecological sites such as Thin Claypan (USDA 2008d).

\section{Validation}

Pasture Scale Measurements. The comparison of remotely sensed seasonal TIN and phenology to field vegetation data collected at the CRLRS suggested that the remote observations were successful in describing actual conditions (Table 3). Fieldmeasured cool-season biomass production and cool-season TIN were greater on the midgrass-dominated pastures than the mixed-grass pastures, following the expected pattern (Sims et al. 1978; Smart et al. 2007). Overall, the relationship between field-measured annual biomass production and TIN by pasture was strong $\left(R^{2}=0.69, P<0.01, n=24\right)$. The field data and TIN corroborated that there was no statistically significant difference in productivity between mixed-grass and midgrass-dominated plant communities, a contradiction to what was expected by the state-and-transition model of the Clayey ecological site. This finding may be due to periodic droughts, such as those in 2002 and 2004, which tend to reduce the productivity difference between mixed-grass and midgrass communities.

The relationship between yearly cool-season percentage of total biomass and cool-season percentage of TIN by pasture was moderately strong $\left(R^{2}=0.58, P<0.01, n=24\right)$. Coolseason percentage of biomass production from field data ranged from $55.4 \%$ to $69.0 \%$, while remotely sensed coolseason percentage ranged from $78.9 \%$ to $84.4 \%$ at the CRLRS (Table 3). This indicated that a significant temporal overlap in cool and warm-season production occurred, leading to overestimation of cool-season production in the remotely sensed data. However, Sims et al. (1978) reported that an average of $78.3 \%$ of production on ungrazed pastures at CRLRS was from cool-season species, much closer to our results. The midgrass pastures had a higher proportion of coolseason production than mixed-grass pastures, leading to a growing season over $2 \mathrm{wk}$ longer in the midgrass-dominated pastures (Table 3). The increased length of the growing season in midgrass-dominated pastures was due to both an earlier spring season and extended fall season; however, the fall season extension was a greater factor.

Carbon Flux Tower. The carbon flux tower is located on one of the mixed-grass plant community pastures at CRLRS. Flux tower PG and mNDVI data have similar yearly phenological profiles (Fig. 7 inset) and interannual differences, as demonstrated by their respective seasonal accumulation (Fig. 7). In both 2007 and 2008, a rapid increase in mNDVI and PG was evident in the first half of the growing season, followed by a slow decline (in the case of 2008), or a rapid decline followed by a period of significant fall regreening (as in 2007; Fig. 7). Drought occurred in 2007 (283 mm of precipitation), resulting in low total PG and TIN values, likely reducing carbon sequestration (Zhang et al. 2011). Precipitation was ample in 2008 (392 mm of precipitation), greatly increasing total PG and TIN. PG was 46.8\% greater in 2008 than in 2007, and TIN was $57.4 \%$ higher (Fig. 7), while only $38.5 \%$ more precipitation occurred. As previously discussed, drought tends to disproportionately affect warm-season productivity; accordingly, cool-season PG was $87 \%$ of the total in 2007 , and only $61 \%$ in 2008 .

In 2007, the spring green-up was fast, with peak mNDVI and PG achieved by late May. Following the growing-season peak, additional biomass production was minimal due to abnormally dry conditions (Fig. 7 inset). During an 8-wk period in the midsummer of 2007, PG accumulation was minimal and no accumulation of TIN occurred, due to a lack of precipitation; this is represented by the vertical portion of the 2007 curve. During this period, the mNDVI values were below the $20 \%$ of maximum mNDVI threshold (van Leeuwen et al. 2010); 
Table 3. Ground-collected and remotely sensed phenometrics for two plant community types at the Cottonwood Range and Livestock Research Station from 2000 to $2005(n=6)$. Time-integrated modified NDVI (TIN) was used as the remotely sensed surrogate of biomass production. Means followed by a different letter indicate a significant difference $(P<0.05)$ within a row.

\begin{tabular}{lrr}
\hline \multirow{2}{*}{ Phenometric } & \multicolumn{2}{c}{ Plant community } \\
\cline { 2 - 3 } & Mixed-grass & Midgrass \\
\hline Field-collected & $649.8 \mathrm{a}$ & $854.3 \mathrm{a}$ \\
Cool-season ${ }^{1}$ production $\left(\mathrm{kg} \cdot \mathrm{ha}^{-1}\right)$ & $437.2 \mathrm{a}$ & $305.6 \mathrm{~b}$ \\
Warm-season $^{2}$ production $\left(\mathrm{kg} \cdot \mathrm{ha}^{-1}\right)$ & $1087.0 \mathrm{a}$ & $1159.9 \mathrm{a}$ \\
Total biomass production $\left(\mathrm{kg} \cdot \mathrm{ha}^{-1}\right)$ & $55.4 \mathrm{~b}$ & $69.0 \mathrm{a}$ \\
Cool season (\%) & & \\
Remotely sensed & $216.1 \mathrm{~b}$ & $232.4 \mathrm{a}$ \\
Cool-season TIN & $63.3 \mathrm{a}$ & $51.1 \mathrm{~b}$ \\
Warm-season TIN & $277.9 \mathrm{a}$ & $280.1 \mathrm{a}$ \\
Total TIN & $78.9 \mathrm{~b}$ & $84.4 \mathrm{a}$ \\
Cool season (\%) & $17.5 \mathrm{a}$ & $16.6 \mathrm{~b}$ \\
Start of season (week of the year) & $37.6 \mathrm{~b}$ & $39.2 \mathrm{a}$ \\
End of season (week of the year) & $20.1 \mathrm{~b}$ & $22.6 \mathrm{a}$ \\
Length of season (wk) & & \\
\hline
\end{tabular}

${ }^{1}$ Cool season grasses included Pascopyrum smithii and Stipa spp.

${ }^{2}$ Warm season grasses included Bouteloua dactyloides and Bouteloua gracilis.

therefore, additional TIN did not accrue. Accumulation of PG and TIN resumed in September and October 2007 following precipitation events. The 2008 seasonal accumulation of TIN and PG was more regular and greater than that in 2007 and had a unimodal profile (Fig. 7), which was the result of evenly distributed precipitation events during the 2008 growing season. Overall, the relationships between the seasonal accumulations of TIN and PG were robust in both 2007 and $2008\left(R^{2}>0.90\right)$, and were best fit by second-order polynomial regressions (Fig. 7).

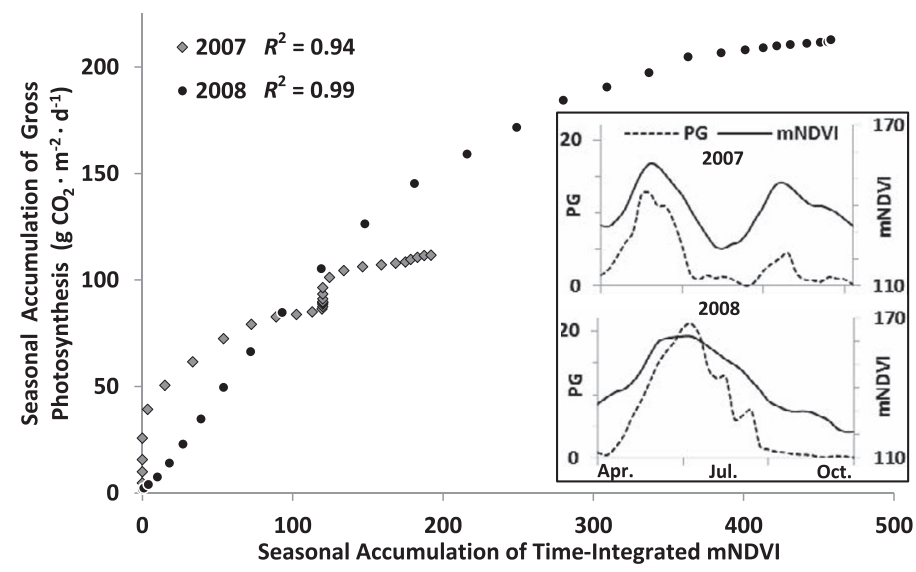

Figure 7. Seasonal accumulation of weekly time-integrated modified NDVI (TIN) and gross photosynthesis (PG) periods for 2007 and 2008 at the Cottonwood, South Dakota, carbon flux tower (located on the Cottonwood Range and Livestock Research Station) and an adjacent Moderate Resolution Imaging Spectroradiometer pixel. Each point represents a week in the 1 April to 31 October period, progressing from left to right (TIN) and bottom to top (PG). Inset figures display the seasonal patterns of PG and mNDVI in 2007 (top) and 2008 (bottom) averaged weekly, corresponding to the seasonal accumulation of PG and TIN.
Pooled weekly mNDVI values from the 2007 and 2008 growing seasons were linearly related $\left(R^{2}=0.67, P<0.01\right)$ to PG data at CRLRS (inset Fig. 7). We observed that introducing a 2-wk time lag to the PG data greatly improved this relationship $\left(R^{2}=0.93, P<0.01\right)$, a pattern also found by Wang et al. (2003) in Kansas tallgrass prairie, possibly associated with the delayed response of mNDVI to active photosynthesis rates. Although only 2 yr of PG data from a single site (representative of the study area as a whole) were available, the data were from years with contrasting precipitation regimes and proved to be well suited to the validation of phenology and TIN results.

\section{MANAGEMENT IMPLICATIONS}

The species diversity and variable weather make native rangelands unpredictable and difficult to model. However, the remotely sensed phenometrics were successful in capturing the characteristics of plant community phenology and productivity. Knowledge of the timing and magnitude of biomass production is critical to the assessment of rangeland health due to the inferences that can be made about species composition. The results of this study clarify the spatial and temporal dynamics (inter and intra-annual) of phenology and biomass production in response to precipitation in the northern mixed-grass prairie. Our approach could be useful to land managers in adjusting the stocking rate and season of grazing to 1) maximize rangeland productivity and profitability (Dunn et al. 2010) and 2) achieve conservation objectives, through a better understanding of management impacts to rangeland phenology and production. These maps increase the efficiency of management by denoting areas where land degradation may be occurring or is likely to occur (i.e., conditions are near a threshold), if current management practices were to continue. If the phenology/productivity of a patch (e.g., pasture) of land is dramatically different than that of the surrounding rangelands or contrasts with the general landscape gradient, it can be presumed that land management practices on that parcel, not climate, soils, or topography, are primarily responsible for the difference. These specific parcels can then be the focus of range improvement practices, field examination, and data collection.

\section{ACKNOWLEDGMENTS}

The authors thank Dave Clay, Suzette Burckhard, and Jesslyn Brown for their thoughtful reviews of earlier versions of this manuscript. Recognition is due to Kurt Reitsma and Kendall Vande Kamp for their support during the writing process. We thank Tilden Meyers, principal investigator of the Ameriflux Cottonwood flux tower site, for providing original flux tower data.

\section{LITERATURE CITED}

Andrew, M. H., I. R. Noble, R. T. Lange, and A. W. Johnson. 1979. A nondestructive method for estimating the weight of forage on shrubs. Australian Rangeland Journal 1:225-231.

Andrew, M. H., I. R. Noble, R. T. Lange, and A. W. Johnson. 1981. The measurement of forage weight: three methods compared. Australian Rangeland Journal 3:74-82. 
Barker, W. T., and W. C. Whitman. 1988. Vegetation of the northern Great Plains. Rangelands 10:266-272.

Bradley, B. A., and J. F. Mustard. 2008. Comparison of phenology trends by land cover class: a case study in the Great Basin, USA. Global Change Biology 14:334-346.

Dunn, B. H., A. J. Smart, A. N. Gates, P. S. Johnson, M. K. Beutler, M. A. Diersen, and L. L. JANSSEN. 2010. Long-term production and profitability from grazing cattle in the northern mixed grass prairie. Rangeland Ecology \& Management 63:233242.

Eneboe, E. J., B. F. Sowell, R. K. Heitschmidt, M. G. Karl, and M. R. Haferkamp. 2002. Drought and grazing: IV. Blue grama and western wheatgrass. Journal of Range Management 55:73-79.

Foody, G. F., AND J. DASH. 2007. Discriminating and mapping the C3 and C4 composition of grasslands in the northern Great Plains, USA. Ecological Informatics 2:89-93.

Fry, J., G. Xian, S. Jin, J. Dewitz, C. Homer, L. Yang, C. Barnes, N. Herold, and J. Wickнам. 2011. Completion of the 2006 National Land Cover Database for the conterminous United States. Photogrammetric Engineering \& Remote Sensing 77:858-864.

Gilmanov, T. G., L. Aires, L. Belelli, Z. Barcza, V. S. Baron, J. Beringer, D. Billesbach, D. Bonal, J. Bradford, E. Ceschia, D. Cook, C. Corradi, A. Frank, D. Gianelle, C. Gimeno, T. Gruenwald, H. Guo, N. Hanan, L. Haszpra, J. Hellman, A. Jacobs, D. A. Johnson, G. Kiely, S. Li, V. Magliulo, E. Moors, Z. Nagy, M. Nasyrov, C. Owensby, K. Pinter, C. Pio, M. Reichstein, M. J. Sanz, R. Scott, J. F. Soussana, T. Svejcar, Z. Tuba, and G. ZHou. 2010. Productivity, respiration, and light-response parameters of world grassland and agro-ecosystems derived from flux-tower measurements. Rangeland Ecology \& Management 63:16-39.

Huete, A. R., K. Didan, T. Miura, E. P. Rodriguez, X. Gao, and L. G. Ferreira. 2002. Overview of the radiometric and biophysical performance of the MODIS vegetation indices. Remote Sensing of Environment 83:195-213.

Jenkerson, C. B., T. Maiersperger, AND G. Schmidt. 2010. eMODIS: a user-friendly data source. Reston, VA, USA: US Geological Survey. Open-File Report 2010-1055. $10 \mathrm{p}$.

Johnson, P. S., C. L. Johnson, AND N. E. West. 1988. Estimation of phytomass for ungrazed crested wheatgrass plants using allometric equations. Journal of Range Management. 41:421-425.

KovalsKYy, V., AND G. M. HeneBRy. 2012. A new concept for simulation of vegetated land surface dynamics-part 1: the event driven phenology model. Biogeosciences 9:141-159.

Lauenroth, W. K., and O. E. Sala. 1992. Long-term forage production of North American shortgrass steppe. Ecological Applications 2:397-402.

Ode, D. J., L. L. Tieszen, And J. C. Lerman. 1980. The seasonal contribution of $\mathrm{C}_{3}$ and $\mathrm{C}_{4}$ plant species to primary production in a mixed prairie. Ecology 61:1304-1311.

Oesterheld, M., J. Loreti, M. Semmartin, and 0. E. Sala. 2001. Inter-annual variation in primary production of a semiarid grassland related to previous-year production. Journal of Vegetation Science 12:137-142.

Paruelo, J. M., and W. K. Lauenroth. 1998. Inter-annual variability of NDVI and its relationship to climate for North American shrublands and grasslands. Journal of Biogeography 25:721-733.

Reed, B. C., J. F. Brown, D. VanderZee, T. R. Loveland, J. W. Merchant, and D. 0. Ohlen. 1994 Measuring phenological variability from satellite imagery. Journal of Vegetation Science 5:703-714.

Ricotta, C., B. C. Reed, and L. T. Tieszen. 2003. The role of $\mathrm{C}_{3}$ and $\mathrm{C}_{4}$ grasses to interannual variability in remotely sensed ecosystem performance over the US Great Plains. International Journal of Remote Sensing 24:4421-4431.

Sala, O. E., W. J. Parton, L. A. Joyce, and W. K. Lauenroth. 1988. Primary production of the central grassland region of the United States. Ecology 69:40-45.

Sims, P. L., AND J. S. Singh. 1978. The structure and function of ten western North American grasslands. III. Net primary production, turnover, and efficiencies of energy capture and water use. Journal of Ecology 66:573-597.

Sims, P. L., J. S. Singh, And W. K. Lauenroth. 1978. The structure and function of ten western North American grasslands. I. Abiotic and vegetational characteristics. Journal of Ecology 66:251-285.
Smart, A. J., B. H. Dunn, P. S. Johnson, L. Xu, and R. N. Gates. 2007. Using weather data to explain herbage yield on three Great Plains plant communities. Rangeland Ecology \& Management 60:146-153.

Swets, D. L., B. C. Reed, J. R. Rowland, and S. E. Marko. 2000. A weighted leastsquares approach to temporal NDVI smoothing. In: Proceedings of the 1999 American Society of Photogrammetric Remote Sensing Annual Conference, From Image to Information; 17-21 May 1999; Portland, OR, USA. CD-ROM.

TaO, F., M. YoKozawa, Z. Zhang, Y. HaYashl, and Y. ISHIGOoKa. 2008. Land surface phenology dynamics and climate variations in the North East China Transect (NECT), 1982-2000. International Journal of Remote Sensing 29:5461-5478.

TateISH, R., AND M. EBatA. 2004. Analysis of phenological change patterns using Advanced Very High Resolution Radiometer (AVHRR) data. International Journal of Remote Sensing 25:2287-2300.

Tieszen, L. L., B. C. Reed, N. B. Bliss, B. K. Wylie, and D. D. DeJong. 1997. NDVI, C3 and $\mathrm{C} 4$ production, and distributions in Great Plains grassland land cover classes. Ecological Applications 7:59-78.

[USDA] US Department of Agriculture-Natural Resources Conservation Service. $2008 \mathrm{a}$. Field office technical guide, Major Land Resource Area 063A: Northern Rolling Pierre Shale Plains, ecological site description: clayey. Available at: https://esis.sc.egov.usda.gov/ESDReport/fsReport.aspx? approved=yes\&id=R063AY011SD. Accessed 10 January 2012.

uSDA-Natural Resources Conservation Service. 2008b. Field office technical guide, Major Land Resource Area 063A: Northern Rolling Pierre Shale Plains, ecological site description: subirrigated. Available at: https://esis.sc.egov.usda.gov/ ESDReport/fsReport.aspx?approved $=$ yes\&id=R063AY003SD. Accessed 20 January 2012.

uSDA-Natural Resources Conservation Service. 2008c. Field office technical guide, Major Land Resource Area 063A: Northern Rolling Pierre Shale Plains, ecological site description: loamy overflow. Available at: https://esis.sc.egov.usda.gov/ ESDReport/fsReport.aspx?approved=yes\&id=R063AY020SD. Accessed 10 January 2012.

USDA-Natural Resources Conservation Service. 2008d. Field office technical guide, Major Land Resource Area 063A: Northern Rolling Pierre Shale Plains, ecological site description: thin claypan. Available at: https://esis.sc.egov.usda.gov/ ESDReport/fsReport.aspx?approved=yes\&id=R063AY015SD. Accessed 10 January 2012.

van Leeuwen, W., J. E. Davison, G. M. Casady, and S. E. Marsh. 2010. Phenological characterization of desert sky island vegetation communities with remotely sensed and climate time series data. Remote Sensing 2:388-415.

Wang, C., B. Jamison, And A. SpICCl. 2010. Trajectory-based warm season grass mapping in Missouri prairies with multi-temporal ASTER imagery. Remote Sensing of Environment, 114:531-539.

Wang, J., P. M. Rich, and K. P. Price. 2003. Temporal responses of NDVI to precipitation and temperature in the central Great Plains, USA. International Journal of Remote Sensing 24:2345-2364.

Wang, J., P. M. Rich, K. P. Price, and W. D. Kettle. 2005. Relations between NDVI, grassland production, and crop yield in the central Great Plains. Geocarto International 20:5-11.

Webb, W., S. Szarek, W. Lauenroth, R. Kinerson, and M. Smith. 1978. Primary productivity and water use in native forest, grassland, and desert ecosystems. Ecology 59:1239-1247.

WHITE, L. M. 1983. Seasonal changes in yield, digestibility, and crude protein of vegetative and floral tillers of two grasses. Journal of Range Management 36:402-405.

Wylie, B. K., D. D. DeJong, L. T. Tieszen, and M. E. Biondini. 1996. Grassland canopy parameters and their relationships to remotely sensed vegetation indices in the Nebraska Sand Hills. Geocarto International 11(3):39-52.

Wylie, B. K., D. J. Meyer, L. L. Tieszen, and S. Mannel. 2002. Satellite mapping of surface biophysical parameters at the biome scale over the North American grasslands-a case study. Remote Sensing of Environment 79:266-278.

Zhang, L., B. K. Wylle, L. Ji, T. Gilmanov, L. L. Tieszen, and D. M. Howard. 2011. Upscaling carbon fluxes over the Great Plains grasslands: sinks and sources, Journal of Geophysical Research 116:1-13. 